Original Research Paper

\title{
The Effectivity of Bioactive Compounds from Montanoa hibiscifolia Benth Plants in inhibiting the Growth of Candida albicans.
}

\author{
Askar Fardiansyah ${ }^{1}$, Khotibul Umam ${ }^{1 *}$, Wawan Sujarwo ${ }^{2}$, Putu Agus Hendra Wibawa ${ }^{2}$ \\ ${ }^{1}$ Fakultas Teknobiologi Universitas Teknologi Sumbawa, Indonesia \\ ${ }^{2}$ Balai Konservasi Tumbuhan Kebun Raya “Eka Karya Bali LIPI, Indonesia
}

\author{
Article History \\ Received : November $07^{\text {th }}, 2020$ \\ Revised : November $20^{\text {th }}, 2020$ \\ Accepted : November $24^{\text {th }}, 2020$ \\ Published : November $28^{\text {th }}, 2020$ \\ *Corresponding Author: \\ Khotibul Umam, \\ Fakultas Teknobiologi \\ Universitas Teknologi Sumbawa, \\ Indonesia; \\ Email: khotibul.umam@uts.ac.id
}

\begin{abstract}
Leucorrhoea is one of common disease in Indonesia that caused by infections of fungus Candida albicans. In dealing with this fungi, the synthetic and even an natural compound had used. Based on pre-screening data of the plants from botanical garden of Eka Karya Lipi Bali, there found apotential plant. This study aims to find the latest alternative treatment using the extract of Montanoa hiscifolia Benth plant from the collection of the "Eka Karya" LIPI Bali Botanical Garden which can inhibit fungal growth $C$. albicans. This research method begins with the literature skrining process using T.K Liem books and direct plant selection. After that proceed with the extraction process of 10 plant samples dose using the evaporator. The plant extracts were then tested directly on 4 types of fungi, from Eka Karya Lipi Bali's collected.The dose used in ths study were $3 \%, 2 \%, 1 \%$ and $0.5 \%$ respectively. The final minimum dosage test was carried out using various concentrations of $M$. hiscifolia Benth plant extract which is the only type of best plant extract that can inhibit growth of $C$. albicans. Therefore, the minimum dosage test was carried out by reducing the concentration from 3 $\%$ to $0,0001 \%$ to determine the minimum dose of extract $M$. hiscifolia Benth inhibiting the fungus $C$. albicans. This study found that at a concentration of $3 \%$ was showed the best results for inhibition zone. On the contrary, at the concentration of $0,0001 \%$, whereas the area of the inhibition zone was 7,2 $\mathrm{mm}$ and categorized as a medium inhibitor. At the last, we were compared the dose of commercial product that oftenly used as Leucorrhoea treatment with $M$. hibiscifolia benth's bioactive and it proven the M. hibiscifolia benth having a hight potential in order to cope the $C$. albicans. Further research might as well to check it bioactive compound that specifically play important role against the $C$. Albican. Beside, eventually develop this plant extract into a real product in order to be used as easy as for the people who need it.
\end{abstract}

Keywords: Montanoa hibiscifolia Benth; Candida albicans; leuchorrhoea

\section{Pendahuluan}

Penyakit infeksi merupakan salah satu penyebab utama masalah kesehatan di Indonesia. Salah satu spesies fungi yang sering menyebabkan infeksi adalah Candida albicans (Wahyuni et al. 2016). Spesies jamur yang banyak menyebabkan penyakit kandidiasis oral dan vulvovaginal di Indonesia yaitu jamur $C$. albicans (Walangare, 2014). Penyakit keputihan yang disebabkan oleh infeksi jamur C. albicans dapat diobati menggunakan berbagai obat-obatan kimia seperti golongan alilamin, azol dan polien (Santosa et al 2003 dalam bennet, 2001) serta secara kuratif dapat memanfaatkan tanaman tertentu (Widyaningrum, 2015).

Tanaman yang paling umum digunakan untuk menghambat pertumbuhan jamur $C$. albicans dan sudah menjadi produk umum di masyarakat adalah tanaman sirih (Putriningrum, Khoiriyah, 2014; Peric et al 2017). Tanaman tersebut dapat menghambat dan mengatasi jamur $C$. albicans disebabkan memiliki kandungan senyawa seperti tannin, alkaloid, terpenoid, flavonoid, polifenol, dan saponin (Fitriana et al 2018). Melihat kondisi saat ini perlu dilakukan studi untuk mendapatkan alternatif tanaman lain yang dapat dimanfaatkan sebagai penghambat dari pertumbuhan jamur $C$. albicans. Berdasarkan metode skrining literatur dan pengujian 
secara langsung dapat diketahui bahwa salah satu jenis tanaman yang dapat menghambat pertumbuhan jamur $C$. albicans yaitu Montanoa hibiscifolia Benth dari famili Asteracea yang merupakan koleksi dari Kebun Raya "Eka Karya" LIPI-Bali.

Tanaman Montanoa pada umumnya telah dimanfaatkan dalam mengobati penyakit yang menyerang daerah mulut manusia (Sabanero, 1995).

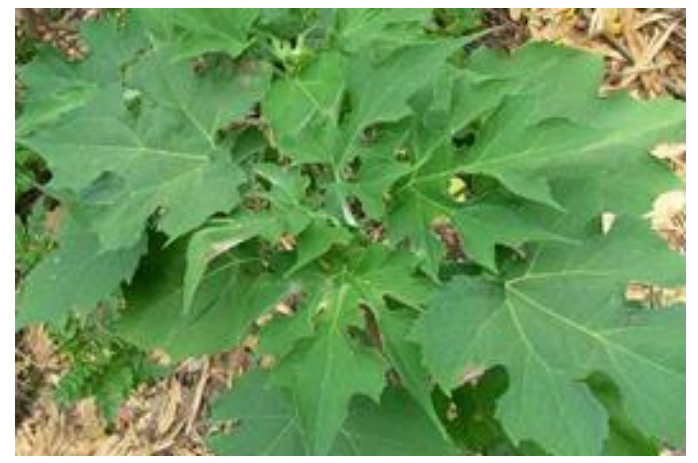

Gambar 1. Tanaman Montanoa hibiscofolia (sumber: Queensland gov.)

Tanaman yang memiliki tinggi 2 - 3 meter ini memiliki kandungan senyawa kimia seperti sesquiterpenoid lakton, tanin, saponin (Braca et al., 2001) dan flavonoid (Muller et al., 2004) yang baik dalam menghambat pertumbuhan jamur. Oleh karenanya, penelitian untuk mencari alternatif tanaman baru dalam mengatasi penyakit keputihan selain sirih pelu untuk dilakukan melalui metode skrining kandidiat tanaman.

\section{Bahan dan Metode}

\section{Waktu dan Tempat}

Penelitian dilaksanakan dari bulan Oktober 2018 Januari 2019 di Laboratorium Konservasi Tanaman Kebun Raya "Eka Karya" LIPI-Bali.maksimum 15\% (untuk penelitian kuantitatif) dari badan artikel.

\section{Alat dan Bahan}

Bahan yang digunakan dalam penelitian ini yaitu menggunakan daun dari tanaman yang merupakan koleksi dari Kebun Raya "Eka Karya" LIPI-Bali dan jamur Candida albicans. Bahan lain yang digunakan meliputi metanol, aquades, media PDA, alkohol 70\%, spiritus, tisu, kertas saring, kapas, alumunium foil, kertas buram, Air bersih, whatman paper disk, kapas, dan plastik pembungkus.

Alat yang digunakan dalam penelitian ini yaitu gelas ukur, neraca analitik, botol ekstrak, laminar air flow (LAF), vortex, batang ose, gunting, vaccum rotary evaporator untuk memekatkan ekstrak, hotplate stirer, corong, cawan petri, tabung reaksi, pipet, pinset, mikropipet $1 \mathrm{ml}$, dan mikropipet $0,1 \mathrm{ml}$.

\section{Prosedur Kerja}

Penelitian ini dilakukan melalui beberapa tahapan, yaitu skrining litertur dan seleksi sampel tanaman, pembuatan ekstrak tanaman, peremajaan jamur $C$. albicans panen jamur $C$. albicans, pengujian awal penelitian, pengujian lanjutan dan dosis minimum, pengamatan hasil zona hambat dan analisis data.

\section{Skrining Literatur dan Seleksi Sampel Tanaman}

Tanaman terpilih dari koleksi Kebun Raya "Eka Karya" Bali yang digunakan dalam penelitian, merupakan tanaman hasil skrining literatur menggunakan buku T.K Liem yang menjelaskan mengenai berbagai manfaat dan kandungan senyawa bioaktif dari berbagai jenis famili dan spesies tanaman. Proses skrining literatur menggunakan 11 literatur buku karya T.K Liem yang bertujuan untuk menseleksi 1549 jenis tanaman menjadi 1 jenis tanaman terbaik.

\section{Pembuatan Ekstrak Tanaman}

Tanaman hasil skrining literatur dan seleksi sampel kemudian diambil daunnya untuk diekstrak. Daun yang digunakan adalah daun yang masih berwarna hijau. Daun segar yang telah dipetik dipisahkan dari batangnya lalu dibersihkan dari kotoran, dicuci dengan air sampai bersih dan ditiriskan. Setelah ditiriskan daun tersebut dipotong-potong dan ditimbang hingga 100 gr lalu daun tersebut dikeringkan dengan cara dijemur dengan cara diangin-anginkan (tidak terkena cahaya matahari langsung) selama 4 - 5 hari. Daun yang telah dikeringkan kemudian dipotong kembali sehingga menjadi ukuran yang lebih kecil.

Tahapan selanjutnya potongan daun yang telah kering tersebut ditimbang kembali pada timbangan analitik untuk melihat berat sampel daun setelah dikeringkan. Sampel daun yang telah ditimbang kemudian dimasukkan ke dalam labu erlenmayer ukuran 1 L dan selanjutnya ditambahkan metanol sebanyak 20 kali dari berat kering sampel daun tersebut sebagai pelarut dan kemudian dihomogenkan.

\section{Pengujian Awal Penelitian}

Pengujian awal penelitian dilakukan dengan menggunakan 10 jenis ekstrak tanaman yang telah diekstrak sebelumnya. Media yang digunakan dalam pengujian ini yaitu menggunakan media PDA padat $10 \mathrm{ml}$, media PDA padat yang telah dibuat dicairkan kemudian dituangkan ke dalam cawan petri setelah itu tunggu media hingga memadat. Kemudian pipet $200 \mu$ inokulum jamur ke dalam cawan petri tersebut dan diratakan menggunakan kapas ke seluruh bagian media agar tersebut. Setelah inokulum telah diratakan ke seluruh media selanjutnya diambil satu buah whatman paper disk yang telah dicelupkan pada ekstrak tanaman dan 
Umam, K., et al. (2020). Jurnal Biologi Tropis, 20 (3): 460 - 466

DOI: http://dx.doi.org/10.29303/jbt.v20i3.2174

kemudian diletakkan di atas permukaan agar tersebut. Setelah itu letakkan cawan petri di tempat yang gelap dan diinkubasi di dalam suhu ruang selama 3 hari.

tanaman yang telah melalui proses skrining literatur dan seleksi di lapangan. Tanaman-tanaman tersebut diambil bagian daun atau bagian rimpang untuk diekstrak dan diuji langsung pada jamur Candida albicans. Penggunaan

Tabel 1. Hasil akhir skrining literatur dan seleksi lapangan koleksi tanaman di Kebun Raya "Eka Karya” LIPI Bali

\begin{tabular}{|c|c|c|c|c|c|}
\hline No & Famili & Nama Spesies & $\begin{array}{c}\text { Asal } \\
\text { Tanaman }\end{array}$ & $\begin{array}{l}\text { Bagian yang } \\
\text { dimanfaatkan }\end{array}$ & Habitat \\
\hline 1 & Combretaceae & Terminalia sp & NTT & Bunga, buah, daun & $400 \mathrm{mdpl}$ \\
\hline 2 & Apocynaceae & Plumeria alba & Bali & $\begin{array}{l}\text { Bunga, daun, } \\
\text { batang }\end{array}$ & 700 mdpl \\
\hline 3 & Asteracea & $\begin{array}{c}\text { Montanoa hibiscifolia } \\
\text { Benth. }\end{array}$ & Afrika & Buah, duan, bunga & $300-2500$ mdpl \\
\hline 4 & Cyperaceae & Carex sp & NTB & $\begin{array}{l}\text { Akar, batang, daun, } \\
\text { biji }\end{array}$ & $1-1000$ mdpl \\
\hline 5 & Dioscoreaceae & Dioscorea bulbifera L & Bali & $\begin{array}{l}\text { Buah, duan, } \\
\text { rimpang }\end{array}$ & 800 mdpl \\
\hline 6 & Cyperaceae & Carex sp & NTT & $\begin{array}{l}\text { Akar, batang, daun, } \\
\text { biji }\end{array}$ & $1-1000$ mdpl \\
\hline 7 & Oxalidaceae & Averrhoa carambola $\mathrm{L}$ & Bali & Buah, bunga, daun & 700 mdpl \\
\hline 8 & Leguminosae & Phanera sp & Bali & $\begin{array}{l}\text { Buah, biji, bunga, } \\
\text { daun }\end{array}$ & $100-2000 \mathrm{mdpl}$ \\
\hline 9 & Myrtaceae & Syzygium aromaticum & Bali & Daun, bunga, biji & 0 - 900 mdpl \\
\hline 10 & Zingiberaceae & $\begin{array}{c}\text { Amomum maximum } \\
\mathrm{Roxb}\end{array}$ & Bali & $\begin{array}{l}\text { Rimpang, daun, } \\
\text { buah, batang }\end{array}$ & $200-600 \mathrm{mdpl}$ \\
\hline
\end{tabular}

\section{Pengamatan Hasil Zona Hambat}

Pengamatan dilakukan dengan cara melihat luas zona hambat yang terlihat dari perlakuan dan kontrol. Pengamatan mulai dari hari pertama setelah dilakukan pengujian sampai dengan hari ketiga pengujian. Proses pengukuran luas zona hambat yang muncul diukur menggunakan penggaris dan proses pengukuran dilakukan 3 sisi yang berbeda dari luas zona hambat. Adapun tolak ukur dalam pengamatan yaitu : diameter zona bening dalam satuan $\mathrm{mm}$.

\section{Analisis Data}

Analisis data dalam penelitian ini menggunakan perhitungan statistik dengan melihat standar eror yang dari hasil perhitungan microsoft excel. Selain itu, analisis data ini juga diperkuat dengan penggunaan analisis data one way ANOVA menggunakan aplikasi SPSS 16.0 terhadap jamur C. albicans.

\section{Hasil dan Pembahasan}

\section{Pengujian Skrining Awal Tanaman}

Penelitian ini menggunakan tanaman koleksi dari kebun raya "Eka Karya" LIPI Bali sebanyak 10 jenis dari bagian daun dan rimpang dimaksudkan kerena kedua bagian tumbuhan tersebut merupakan bagian yang cukup memadai jumlahnya ketika dilakukan seleksi di lapangan.

Penggunaan bagian daun dan rimpang juga mengikuti studi literatur yaitu buku T.K Liem (1997, 1998, 1999) dalam 11 volume yang menjelaskan bahwa kandungan kimia pada daun dan rimpang merupakan organ yang bisa mewakili ketersebaran kandungan bioaktif yg ada di tanaman. Penelitian ini menggunakan tahapan skrining literatur dan seleksi lapangan yang bertujuan untuk menyeleksi tanaman awal yang berjumlah 1549 tanaman menjadi 10 jenis tanaman yang memenuhi kriteria kandungan senyawa metabolit sekunder, kemampuan antijamur dan keberadaan tanaman di lapangan (Tabel.1).

Tabel 1 menujukkan bahwa 10 jenis kandidiat yang diskrining dapat diketahui asal, jenis dan habitat aslinya. Secara umum penggunaan organ daun menjadi yang paling dominan dalam pembuatan ekstrak tanaman. Namun, organ-organ lain pada tumbuhan seperti bunga, biji, rimpang, batang, dan akar juga masih dapat dimanfaatkan untuk proses ekstraksi sehingga didapatkan kandungan senyawa metabolit sekunder. Hal ini diperkuat oleh pendapat Peric et al (2019), yang menjelaskan bahwa 
semua bagian tumbuhan dapat digunakan dalam proses ekstraksi.

Tanaman yang telah diperoleh dari hasil skrining selanjutnya melalui tahapan ekstraksi dengan menggunakan bagian daun tanaman yang telah diseleksi dengan melihat kondisi jumlah organ yang mencukupi untuk proses ekstraksi. Hal ini dikarenakan dalam proses ekstraksi dengan metode evaporasi memerlukan berat organ tanaman sebanyak 100 gr. Penggunaan bagian organ tanaman sebanyak 100 gr dimaksudkan agar jumlah kandungan senyawa metabolit sekunder yang didapat tidak terlalu sedikit (Tjay, 2007).

Tahapan selanjutnya setelah memperoleh ekstrak tanaman yakni pengujian langsung dilakukan pada 4 jenis jamur yang merupakan koleksi laboratorium konservasi tanaman di LIPI Bali yaitu jamur Fusarium solani, Chlodosporium sp, Aspergilus niger, dan C. Albicans (Tabel 2). Tujuan dilakukannya pengujian pada 4 jenis jamur yang berbeda yaitu untuk mengetahui kemampuan antijamur yang dimiliki oleh 10 jenis tanaman hasil skrining dan untuk dilakukan proses seleksi untuk mendapatakan satu jenis tanaman terbaik dalam menghambat pertumbuhan jamur.

Tabel 2 menunjukkan hasil dari pengujian awal terhadap 10 jenis tanaman yang didapatkan dari hasil skrining literatur. Pengujian tersebut menunjukkan bahwa dari 10 jenis tanaman yang diujikan pada 4 jenis jamur yaitu F. solani, Chlodosporium sp, A. niger, dan $C$. pengujian pada jamur $C$. albicans menunjukkan hasil yang menarik hal ini terlihat bahwa hanya satu jenis ekstrak tanaman yang dapat menghambat pertumbuhan jamur C. albicans yakni ekstrak tanaman M. hibiscifolia Benth. Tanaman $M$. hibiscifolia Benth dapat menghambat pertumbuhan jamur disebabkan memiliki kandungan senyawa bioaktif seperti terpenoid terutama diterpenoid (Villa et al, 2014) dan beberapa kandungan senyawa metabolit lain seperti tanin, saponin (Braca et al., 2001) serta flavonoid (Muller et al., 2004). Menurut Allison (2004), perbedaan struktur penyusun dinding sel pada $C$. albicans yang berupa polisakarida (mannan, glukan, kitin) menyebabkan tidak mudahnya suatu senyawa metabolit sekunder dalam memecah dinding selnya. Berbeda dengan ketiga jamur lainnya yang memiliki dinding sel yang tersusun dari protein dan lipid yang sangat rentan terhadap senyawa metabolit sekunder tanaman sehingga dinding sel jamur tersebut mudah pecah (Sulasmi, 2015).

Pengujian lanjutan ekstrak tanaman montanoa hibiscifolia benth sebagai agen penghambat jamur candida albicans

Kemampuan Ekstrak Tanaman M. hibiscifolia Benth dalam menghambat Jamur $C$. albicans pada uji awal menunjukkan hasil yang paling baik dibandingkan 9 jenis tanaman lainnya, sehingga perlu dilakukan pengujian lanjutan. Tujuan dari pengujian lanjutan yang dilakukan yaitu untuk mengetahui konsentrasi minimum

Tabel 2. Hasil Pengujian awal terhadap 10 jenis tanaman hasil skrining litertur dengan pengujian pada 4 jenis jamur

\begin{tabular}{cccccc}
\hline No & Nama Tanaman & $\begin{array}{c}\text { Fusarium } \\
\text { solani }\end{array}$ & $\begin{array}{c}\text { Aspergilus } \\
\text { niger }\end{array}$ & Chlodosporium & $\begin{array}{c}\text { Candida } \\
\text { albicans }\end{array}$ \\
\hline 1 & Terminalia $s p$ & Positif & Negatif & Positif & Negatif \\
2 & Plumeria alba & Negatif & Negatif & Positif & Negatif \\
3 & Montanoa hibiscolia Benth & Positif & Positif & Positif & Positif \\
4 & Carex sp NTT (30) & Positif & Negatif & Positif & Negatif \\
5 & Dioscorea bulbifera L & Positif & Negatif & Negatif & Negatif \\
6 & Carex sp NTB (27) & Positif & Negatif & Negatif & Negatif \\
7 & Averrhoa carambola L & Positif & Positif & Negatif & Negatif \\
8 & Phanera $s p$ & Negatif & Negatif & Positif & Negatif \\
9 & Syzygium aromaticum & Positif & Negatif & Negatif & Negatif \\
10 & Amomum maximum Roxb & Positif & Negatif & Negatif & Negatif \\
\hline
\end{tabular}

Albicans terlihat bahwa tanaman M. Hibiscifolia Benth memiliki hasil positif untuk melakukan penghambatan terhadap pertumbuhan semua jenis jamur yang ada, hal ini dilihat dari zona hambat yang terbentuk dari ekstrak tanaman tersebut ketika diujikan ke jamur. Hasil dari ekstrak tanaman $M$. hibiscifolia Benth dalam menghambat pertumbuhan jamur $C$. albicans.

Hasil ekstraksi pada tanaman M. hibiscifolia Benth dalam penelitian ini menunjukkan kadar senyawa metabolit sekunder sebesar 3,5\% melalui proses 
evaporasi. Oleh karena itu, dalam tahapan uji lanjutan ini menggunakan pengurangan konsentrasi ekstrak tanaman dalam range $0,25 \%$ hingga $1 \%$ sehingga dalam uji lanjutan menggunakan konsentrasi $3 \%, 2 \%, 1 \%$, dan 0,5 $\%$ (Gambar 3.1) dengan tiga kali pengulangan untuk medapatkan hasil luas zona hambat yang akurat. Penggunaan konsentrasi yang semakin rendah merupakan suatu cara untuk mengetahui efektivitas daya hambat senyawa metabolit sekunder pada tanaman $M$. hibiscifolia Benth. Hal ini berkorelasi dengan tujuan dari penelitian ini yaitu untuk mendapatkan dosis minimum dari ekstrak tanaman M. hibiscifolia Benth.

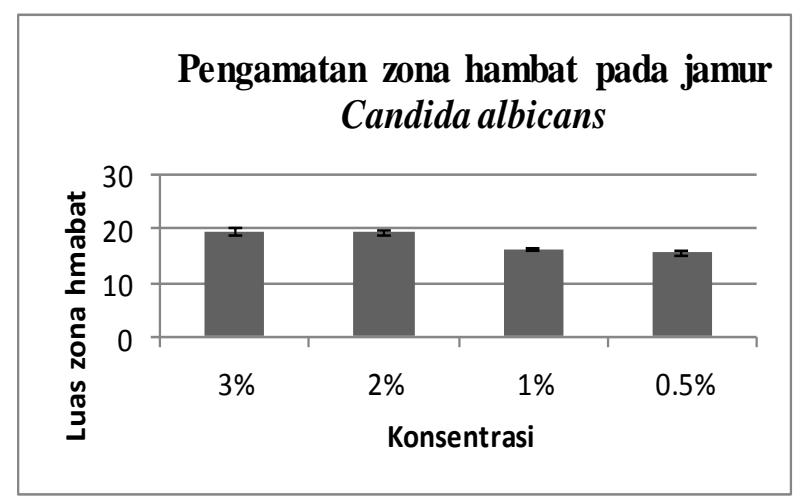

Gambar. 2. Pengujian ekstrak tanaman M. hibiscifolia Benth dalam menghambat pertumbuhan jamur C. Albicans.

Berdasarkan gambar 1 terlihat bahwa konsentrasi ekstrak daun Montanoa hibiscifolia Benth berbanding lurus dengan zona hambat yang terbentuk, dimana pada konsentrasi $3 \%$ merupakan konsentrasi tertinggi dengan panjang diameter terbesar yaitu 19,5 mm, sedangkan pada konsentrasi $2 \%$ tidak terlalu berbeda dengan konsentrasi $3 \%$ namun masih memiliki perbedaan luas zona bening yang terbentuk. Jika dibandingkan dengan dengan konsentrasi $1 \%$ dan 0,5\% maka akan menghasilkan hasil yang berbeda. Hal ini dapat dikatakan bahwa, semakin tinggi konsentrasi maka akan semakin besar pula zona hambat yang terbentuk. Sesuai yang diungkapkan Chuang et al. (2007), senyawa yang terkandung dalam ekstrak $M$. hibiscifolia Benth menyebabkan pecahnya membran sitoplasma sel jamur sehingga komponen intraseluler mengalami kerusakan dan mengarah pada kematian sel jamur.

Menurut Davis (1971 dalam Villa, 2015), konsentrasi 0,5 \% ekstrak M. hibiscifolia Benth yang merupakan konsentrasi terkecil pada pengujian ini masih dikategorikan sebagai penghambat antijamur yang kuat karena berada dibatas angka 10 - $20 \mathrm{~mm}$ yaitu sebesar 15,47 mm. Oleh karena itu, perlu dilakukan pengujian dosis minimum untuk melihat hingga konsentrasi minimum berapakah ekstrak $M$. hibiscifolia Benth dapat melakukan penghambatan terhadap jamur $C$. albicans.

\section{Efektivitas senyawa bioaktif Montanoa hibiscifolia} benth

Efektivitas senyawa bioaktif tanaman Montanoa hibiscifolia Benth dalam menghambat petumbuhan jamur Candida albicans dilakukan dalam 20 kelompok perlakuan dan penggunaan sabun sirih yang sudah beredar di masyarakat sebagai kontrol positif. Dalam penelitian ini digunakan pengulangan sebanyak 3 kali untuk mendapatkan hasil yang akurat sehingga dapat membuktikan adanya pengaruh konsentrasi senyawa bioaktif tanaman $M$. hibiscifolia Benth dalam menghambat pertumbuhan jamur $C$. albicans. Pengujian efektivitas ini bertujuan untuk mengetahui efektivitas daya hambat dari senyawa bioaktif tanaman $M$. hibiscifolia Benth terhadap jamur $C$. albicans yang dibandingkan dengan kontrol positif. Penelitian ini menggunakan uji ANOVA dan uji lanjutan menggunakan Duncan Multiple Range Test (DMRT) dengan tingkat kepercayaan $95 \%$ (tabel 3). Hasil penelitian ini diperoleh dengan mengukur diameter zona hambat yang terbentuk disekitar paper disk dengan menggunakan penggaris dalam satuan mm.

Berdasarkan hasil uji DMRT, efektivitas setiap perlakuan tanaman Montanoa hibiscifolia Benth menunjukkan hasil yang sama jika dibandingkan dengan kontrol positif dalam menghambat pertumbuhan jamur Candida albicans. Tabel 3 menunjukkan bahwa hasil uji DMRT pada semua perlakuan yang diuji memberikan hasil yang berbeda nyata antar perlakuan yang ada. Hasil pengujian lanjutan DMRT menunjukkan bahwa terdapat perlakuan yang yang memiliki hasil yang hampir serupa dengan perlakuan kontrol positif yaitu perlakuan dengan konsentrasi Montanoa hibiscifolia Benth 2,0\% yang menunjukkan angka 19,40 mm dan konsentrasi Montanoa hibiscifolia Benth 3,0 \% yang menunjukkan angka 19,51 mm. Dua data perlakuan diatas merupakan hasil terbaik yang memiliki hasil serupa dengan kontol positif. Namun, yang menjadi perlakuan yang efektif dalam menghambat jamur Candida albicans adalah konsentrasi Montanoa hibiscifolia Benth 2,0 \%. Konsentrasi Montanoa hibiscifolia Benth 2,0 \% dipilih sebagai perlakuan yang paling efektif adalah karena pada perlakuan ini menggunakan jumlah bahan yang lebih minim dibandingkan dengan konsentrasi Montanoa hibiscifolia Benth 3,0 \% namun memiliki hasil yang serupa.

Daya hambat yang dihasilkan pada masing masing konsentrasi menunjukkan bahwa zona hambat yang dihasilkan akan semakin besar sesuai dengan peningkatan konsentrasi. Hal tersebut menunjukkan bahwa kemampuan antijamur dari senyawa bioaktif tanaman akan semakin tinggi pada konsentrasi yang tinggi pula dan akan berkurang dengan menurunnya konsentrasi senyawa bioaktif tanaman tersebut (Sugianitri, 2011; Fitriana, 2018; Rahayu, 2013). Hal tersebut tersebut berbanding terbalik dengan ekstrak tanaman Montanoa hibiscifolia Benth yang masih 
Tabel 3. Hasil uji Duncan Multiple Range Test (DMRT) (tingkat kepercayaan $95 \%$ ) terhadap luas zona hambat jamur Candida albicans

\begin{tabular}{|c|c|c|}
\hline No & Perlakuan & Rata - rata \\
\hline 1 & Konsentrasi $0,00010 \%$ & $7,19^{\mathrm{a}}$ \\
\hline 2 & Konsentrasi $0,00025 \%$ & $10,3^{\mathrm{b}}$ \\
\hline 3 & Konsentrasi $0,00050 \%$ & $10,6^{\mathrm{b}}$ \\
\hline 4 & Konsentrasi $0,00075 \%$ & $10,71^{\mathrm{b}}$ \\
\hline 5 & Konsentrasi 0,0010\% & $10,51^{\mathrm{b}}$ \\
\hline 6 & Konsentrasi 0,0025\% & $10,82^{\mathrm{b}}$ \\
\hline 7 & Konsentrasi $0,0050 \%$ & $13,19^{\mathrm{cd}}$ \\
\hline 8 & Konsentrasi 0,0075\% & $12,95^{\mathrm{cd}}$ \\
\hline 9 & Konsentrasi 0,010\% & $11,38^{\mathrm{bc}}$ \\
\hline 10 & Konsentrasi $0,025 \%$ & $14,44^{\mathrm{de}}$ \\
\hline 11 & Konsentrasi 0,050\% & $14,48^{\text {de }}$ \\
\hline 12 & Konsentrasi 0,075\% & $15,11^{\mathrm{def}}$ \\
\hline 13 & Konsentrasi $0,1 \%$ & $14,86^{\mathrm{de}}$ \\
\hline 14 & Konsentrasi 0,2\% & $15,83^{\mathrm{ef}}$ \\
\hline 15 & Konsentrasi 0,3\% & $17,11^{\mathrm{fg}}$ \\
\hline 16 & Konsentrasi 0,4\% & $18,19^{\text {gh }}$ \\
\hline 17 & Konsentrasi 0,5\% & $15,47^{\mathrm{ef}}$ \\
\hline 18 & Konsentrasi $1,0 \%$ & $16,19^{\mathrm{efg}}$ \\
\hline 19 & Konsentrasi 2,0\% & $19,40^{\mathrm{h}}$ \\
\hline 20 & Konsentrasi 3,0\% & $19,51^{\mathrm{h}}$ \\
\hline 21 & Kontrol Positif (Konsentrasi 5,75 \%)* & $34,81^{\mathrm{i}}$ \\
\hline
\end{tabular}

*kontrol positif menggunakan produk komersil

menunjukkan luas zona hambat pada konsentrasi $3 \%$, dan dapat dikatakan lebih efektif karena dengan konsentrasi 3 $\%$ tapi memiliki luas zona hambat yang kuat dibandingkan dengan kontrol positif (produk komersil) yang ketika diturunkan namun tidak memunculkan luas zona hambat.

\section{Kesimpulan}

Pengujian tanaman Montanoa hibiscifolia Benth dari genus Asteracea terhadap jamur Candida albicans menjadi kandidat hasil skrining terbaik dari koleksi tanaman yang berada di Kebun Raya "Eka Karya" Bali LIPI. Sedangkan dari aspek pengujian zona hambat tanaman dengan variasi perlakuan diperoleh bahwa perlakuan dengan konsentrasi rendah ke tinggi (0.5-3\%) menunjukkan daya hambat yang sebanding pula, dimana semakin tinggi konsentrasi, maka semakin besar pula zona hambat yang terbentuk. Penelitian ini membuktikan bahwa perbandingan penggunaan kandidat senyawa aktif tanaman Montanoa hibiscifolia Benth dengan produk komersil (control) berpotensi lebih efektif dalam mencegah pertumbuhan C. albicans.

\section{Ucapan terima kasih}

Terimakasih penulis sampaikan kepada instansi Kebun Raya "Eka Karya" Bali LIPI atas kesmpatan dan support penuhnya dalam penyelesaian penelitian ini serta terimakasih pula untuk dukungan dari fakultas Teknobiologi, Universitas Teknologi Sumbawa untuk terlaksananya riset ini melalui kerjasama kedua pihak.

\section{Referensi}

Braca A, Cioffi G, Morelli I, Venturella F, Pizza C, \& De Tommasi N (2001). Two new sesquiterpene lactones from Montanoa tomentosa ssp. microcephala. Plant. Med., 67: 774-776. DOI: https://dx.doi.org/10.1055/s-2001-18362 
Umam, K., et al. (2020). Jurnal Biologi Tropis, 20 (3): 460 - 466 DOI: http://dx.doi.org/10.29303/jbt.v20i3.2174

Chuang, P. H., C.W. Lee, J. Y. Chou, M. Murugan, B. J. Shieh, \& H. M. Chen. (2007). Antifungal activity of crude extracts and essential oil of Moringa oleifera Lam. Bioresource Technology, 98:232236.

DOI: https://doi.org/10.1016/i.biortech.2005.11.003

Fitriana, R. M. A., Estikomah, S. A., \& Marfu'ah, N. (2018). Formulasi Sediaan Sabun Cair Ekstrak Daun Sirih Hijau (Piper battle folium L.) dan ekstrak bawang putih (Allium sativum L.) sebagai antijamur Candida albicans. Pharmaceutical Journal of Islamic Pharmacy, 2(2), 23-30. https://doi.org/10.21111/pharmasipha.v2i2.3040

Kurniawan, J. A. (2009). Uji Aktivitas Antijamur Ekstrak Rimpang Binahong (Anredera cordifolia (Tenore) Steen) Terhadap Jamur Candida albicans serta Skrining Fitokimianya(Doctoral dissertation, Univerversitas Muhammadiyah Surakarta). http://eprints.ums.ac.id

Muller S, Murillo R, Castro V, Brecht V, \& Merfor I (2004). Sesquiterpene lactones from Montanoa hibiscifolia that inhibit the transcription factor NFkappa B. J. Nat. prod., 67: 622-630 https://doi.org/10.1021/np034072q

Natta, L., Orapin, Krittika \& Pantip (2008). Essensial Oil from Zingiberaceae for Anti Food-Borne Bacteria. International Food Research Journal. 15, (3), 337346.

https://iternationalfoodresearchjournal.academia.e $\mathrm{du}$

Perić, M., Rajković, K., Lemić, A. M., Živković, R., \& Arsenijević, V. A. (2019). Development and validation of mathematical models for testing antifungal activity of different essential oils against Candida species. Archives of Oral Biology, 98, 258-264. DOI: https://doi.org/10.1016/j.archoralbio.2018.11.029

Putriningrum, R., \& Khoiriyah, A. (2014). Kajian Efek Sinergistik Anti Jamur Ekstrak Biji Pinang (Areca Cathechu, L.) Dan Daun Sirih Merah (Piper Betle L.) Untuk Pencegahan Kandidiasis Vulvovaginal. Jurnal Kesehatan Kusuma Husada. https://jurnal.ukh.ac.id

Sabanero M, Quijano L, Rios T, \& Trejo R (1995). Encelin: a funal Growth Inhibitor. Plant Med., 61: 185-186. DOI: https://doi.org/10.1055/s-2006958046

Santosa, D., \& Purwantini, I. (2003). Aktivitas Antifungi (Candida albicans) Beberapa tanaman yang secara
Empirik Digunakan sebagai Obat Keputihan. Jurnal Alam Indonesia (The Indonesian Journal of Natural Product), 2(3). Http://academia.edu

Sirait M. (2007). Penuntun fitokimia dalam farmasi. Bandung: Institut teknologi Bandung.

Sugianitri, N.K. (2011). Ekstrak Biji Buah Pinang (Areca catechu L.) Dapat Menghambat Pertumbuhan Koloni Candida albicans secara in vitro pada Resin Akrilik Heat Cured. Skripsi, Program Studi Ilmu Biomedik Universitas Udayana, Bali.

Sulasmi, E.S., Prabaningtyas, S., \& Sari, M.S. (2015). Identification of Tannin Compound of Three Genus Pteridophytes in Taman Hutan Raya Raden Soerjo. Proceeding the 6 th International Conference in Green Tecnology. Malang. Maulana Malik Ibrahim University, Indonesia diseminarkan pada 18 November 2015 .

Tjay H, Rahardja K. (2007). Obat-obat penting kasiat, penggunaan, dan efek sampingnya. Jakarta: Gramedia. h 29-32.

Tuna M. (2015). Uji daya hambat ekstrak daun sirsak (Annona murcata L) terhadap pertumbuhan Staphylococcus aureus secara in vitro [Skripsi]. Manado. Universitas sam ratulangi. http://ejournal.unsrat.ac.id

Villa-Ruano, N., \& Lozoya-Gloria, E. (2014). Antifertility and other biological activities of zoapatle (Montanoa spp.) with biotechnological application. Boletín latinoamericano y del Caribe de plantas medicinales y aromáticas, 13(5), 415436. http://redalyc.org

Wahyuni, Sry et al. (2016). Uji Daya Hambat Ekstrak Bawang Hutan (Eleutherine palmifolia (L.) dari Matantimali terhadap Pertumbuhan Jamur. Jurnal Akademika Kimia 5(2): 98-102. DOI: https://doi.org/10.22487/j24775185.2016.v5.i2.80 30

Walangare, T., Hidayat, T., \& Basuki, S. (2014). Profil Spesies Candida pada Pasien Kandidiasis Oral dengan Infeksi HIV\&AIDS. Berkala Ilmu Kesehatan Kulit dan Kelamin, 1(26): 29-35. DOI: http://dx.doi.org/10.20473/bikk.V26.1.2014.1-7

Widyaningrum, Trianik \& Try Wahyuni (2015). Uji Aktivitas Antifungi Ekstrak Etanol Daun Sidaguri (Sida rhombifolia) terhadap Candida albicans. Jurnal Global 1(1): 377-384. http://researchreport.umm.ac.id 